\title{
DAIRY CATTLE BIOGAS USAGE IN MICROTURBINES FOR ENERGY GENERATION AND THERMAL EXPLOITATION
}

\author{
Marcio Y. Hirano ${ }^{1 *}$, Celso L. da Silva ${ }^{2}$ \\ ${ }^{1 *}$ Corresponding author. Universidade Estadual Paulista/ UNESP, Bauru - SP, Brasil. E-mail: mayuhi@ hotmail.com
}

\section{KEYWORDS}

energy exploitation, biogas, dairy cattle, microturbine.

\begin{abstract}
The increase in confined cattle breeding reflects the modernization and automation of farming, which has significantly intensified in recent years and caused an increase in the energy demand of rural properties. This study investigated the use of biogas generated from dairy cattle manure confined in gas microturbines on a farm to generate electricity and the energy use of exhaust gases. At the end of the study, 6,195 to 16,077 $\mathrm{kWh} \mathrm{month}^{-1}$ of electricity was obtained, which corresponds to $43.3 \%$ of the property's self-sufficiency energy demand. By performing an exhaust gas energy exploitation, between 6.8 and 13.6 $\mathrm{m}^{3}$ day $^{-1}$ of water heated to $368 \mathrm{~K}$ can be produced, or between 11,880 and 23,661 $\mathrm{kWh}$ month ${ }^{-1}$ of cooling capacity can be obtained using a liquid cooler.
\end{abstract}

\section{INTRODUCTION}

A feedlot or confinement system, which has intensified in recent years, consists of distributing animals in small lots and raising them in enclosed pens to control the supply of food and water and obtain an increase in milk production and a decrease in time to slaughter (beef cattle). However, the use of a containment system requires some care regarding the disposal of the produced waste. The feces, urine, beds and feed leftovers produced during livestock farming should be adequately treated and destroyed. Incorrect disposal of manure can cause soil and air pollution, the eutrophication of groundwater and waterbodies, and the proliferation of vectors, such as flies, which can transmit diseases to animals and humans. According to Fonseca et al. (2014), bovine feces contain several genera of nematodes. Gregory et al. (2014) identified the presence of bacteria, such as Escherichia coli.

According to Da Costa et al. (2013), the use of biodigesters helps correct environmental and health problems in rural areas. The biodigester is a chamber in which organic waste is deposited. With the help of certain groups of anaerobic bacteria, the potential for waste pollution and health risks can be reduced. At the end of the biodigestion process, biogas, which is a mixture of gases formed during the anaerobic digestion process and primarily consists of methane gas $\left(\mathrm{CH}_{4}\right)$ and carbon dioxide $\left(\mathrm{CO}_{2}\right)$, is obtained. Methane gas is a single chain hydrocarbon that has high calorific value; its release into the atmosphere should be avoided because it intensifies the global warming greenhouse effect. Another byproduct of the process is biofertilizer-an inert effluent and excellent organic fertilizer that is capable of restoring soil microbiota, which increases its productivity.

Biogas is a renewable fuel that can be used as an alternative fuel source in rural properties for heating water and spaces, grain drying, food cooking, lighting, and electricity generation. The most common form of biogas use is its conversion to electric and thermal energy. The conversion to electricity currently relies on several available technologies, with the best results achieved using specific microturbines that can present satisfactory energy yields when employed for energy generation, cogeneration and trigeration purposes.

Modern microturbines can operate with the biogas that is directly collected from the biodigester, without the need for prior treatment. The electricity produced by the microturbine can be employed at the farm, which reduces production costs, or can be passed to the power utilities through the Energy Compensation System, which generates credits that can be applied to energy bills. The use of microturbines is well regarded because these machines can have different power, are compact and light (can be installed anywhere), have low noise and vibration levels, are reliable and require minimal maintenance. They also have great flexibility in terms of the fuel consumption, which enables their continuous operation during situations with low or no biogas production, and they emit a low level of pollutants, which precludes the need to use filters and gas scrubbers that increase the cost of the produced energy. The heat that is carried away by the exhaust gases from the microturbine can be reused through the use of heat recovery units, which transfer heat from the exhaust

\footnotetext{
${ }^{2}$ Universidade Estadual Paulista/ UNESP, Bauru - SP, Brasil

Received in: 12-1-2015

Accepted in: 6-4-2018
} 
gases to a working fluid that can be employed for heating or cooling purposes.

This study sought to assess the viability of the use of biogas derived from the decomposition of dairy cattle manure in microturbines, for the purpose of electricity generation; the potential for energy use of the exhaust gases in water heating and refrigeration systems via absorption; and the electricity generation potential per animal. An analysis of the implementation costs of the system and an estimate of energy savings of the rural property were performed.

\section{MATERIAL AND METHODS}

To conduct this study, data and information were collected from a rural property that was dedicated to dairy cattle production and product catalogs of microturbine, compressors, heat recovery units, and liquid chillers (absorption chillers). The rural property is located in the municipality of Buritama in the state of São Paulo (SP), Brazil, with a total herd of 336 Holstein cattle, which are raised in a confinement (feedlot) system. The livestock's waste, such as animal feces, urine and wash water of 240 animals, are collected through gutters and grates and transported to a pre-fermentation box, where additional water is added and waste is diluted. After dilution, the waste is piped to a Canadian biodigester, with a feed channel and a suction channel. The suction channel is connected to a hydraulic pump, which compresses the organic effluent and distributes it in the biodigester at eight injection points in an upstream direction. This process enables the mixing and uniformization of both the organic material and the population of anaerobic bacteria inside the biodigester. After the anaerobic biodigestion process, the liquid effluent is used for the fertigation of corn and Napier grass, which are used as feed for cattle.

The produced biogas is collected by a pipeline system and used for electricity generation. The amount of produced biogas depends on the quality and quantity of organic matter available for biodegradation. Based on some measurements and observations provided by the owner and site staff, each dairy cow produces an average of approximately $40 \mathrm{~kg}$ of fresh manure daily. Baungratz et al. (2013) suggests that the conversion potential of dairy cattle manure can vary from 0.040 to $0.049 \mathrm{~m}^{3}$ of biogas per $\mathrm{kg}$ of fresh manure. Therefore, the biogas production can be estimated by the following expression:

$$
\mathrm{V}_{\text {biogas }}=\mathrm{Q} \cdot \mathrm{P}_{\mathrm{c}}
$$

Where,

$$
\begin{aligned}
& \mathrm{V}_{\text {biogas }}=\text { Volume of biogas produced }\left[\mathrm{m}^{3}\right] ; \\
& \mathrm{Q}=\text { Amount of organic matter consumed }[\mathrm{kg}] \text {, } \\
& \mathrm{P}_{\mathrm{c}}=\text { Average conversion potential of organic matter } \\
& \text { to biogas }\left[\mathrm{m}^{3} \text { of biogas } \mathrm{kg} \text { of manure }{ }^{-1}\right] \text {, at an } \\
& \text { ambient temperature of } 30{ }^{\circ} \mathrm{C} \text {, with effluent stirring } \\
& \text { and without the addition of accelerators. }
\end{aligned}
$$

Due to the predominance of methane gas and carbon dioxide in its composition, the calorific value of the biogas can be estimated by the amount and calorific value of the methane gas in the biogas. Therefore, the calorific value of the biogas can be obtained by the following equation:
Where,

$$
\mathrm{LCV}_{\text {biogas }}=\left(\%_{\mathrm{CH} 4} \cdot \mathrm{LCV}_{\mathrm{CH} 4}\right)
$$

$$
\begin{aligned}
& \mathrm{LCV}_{\text {biogas }}=\text { Lower Calorific Value of biogas } \\
& {\left[\mathrm{kJ} \mathrm{Nm}^{-3}\right] \text {; }} \\
& \%_{\mathrm{CH} 4}=\text { Quantity (percentage) of methane gas in } \\
& \text { the biogas, } \\
& \mathrm{LCV}_{\mathrm{CH} 4}=\text { Lower Calorific Value of methane gas } \\
& {\left[\mathrm{kJ} \mathrm{Nm}^{-3}\right] .}
\end{aligned}
$$

The energy potential of the produced biogas can be estimated based on the volume of biogas produced and its calorific value according to the following equation:

$$
\mathrm{E}_{\mathrm{LCV}}=\mathrm{LCV}_{\text {biogas }} * \mathrm{~V}_{\text {biogas }}
$$

Where

$$
\mathrm{E}_{\mathrm{LCV}}=\text { Energy potential provided by the biogas }[\mathrm{kJ}] \text {. }
$$

The amount of generated electricity depends on the type of equipment and its power generation capacity, the quality of the fuel, and the ambient operating conditions. Among the several models of microturbines, the Capstone CR30 microturbine, which can be directly supplied with biogas with a low-methane gas content and high levels of contaminants, was selected for analysis. In addition, the microturbine is a simple equipment, has relatively low cost, and satisfies the energy demand of the analyzed farm. The CR30 microturbine operates at 96,000 rpm, when the spent fuel provides $440 \mathrm{MJ} / \mathrm{h}$ of power at a pressure of 414 to $483 \mathrm{kPa}$. In addition, the microturbine has a three-phase electric generator $(400 / 480 \mathrm{VAC})$ with $50 / 60 \mathrm{~Hz}$, a capacity of $30 \mathrm{~kW}$, and an electrical efficiency of $26 \%$ (at $288 \mathrm{~K}$ ) that can be directly connected to the network or equipment. Exhaust gases leave the microturbine at $275^{\circ} \mathrm{C}$ $(548 \mathrm{~K})$ at a flow rate of $0.31 \mathrm{~kg} / \mathrm{s}$.

The electricity generated can be estimated by the electrical performance of the generator (supplied by the manufacturer) as a function of the ambient operating temperature. Thus, the electricity generation capacity of the microturbine is obtained by the following equation:

$$
\mathrm{E}_{\text {Mic }}=\mathrm{P}_{\text {Mic }} \cdot \frac{\mathrm{E}_{\mathrm{LCV}}}{\phi_{\text {Mic }}}
$$

Where,

$\mathrm{E}_{\mathrm{Mic}}=$ Electricity generated by the microturbine $[\mathrm{kWh}]$;

$\mathrm{P}_{\text {Mic }}=$ Electric power generated by the microturbine at ambient operating conditions $[\mathrm{kW}]$,

$\phi_{\text {mic }}=$ Energy flow required by the microturbine to operate $\left[\mathrm{kJ} \mathrm{h}^{-1}\right]$;

The biogas must enter the microturbine at a high working pressure (414-483 $\mathrm{kPa}$ ). The MEHRER TRE 200 compressor, which operates with toxic and flammable gases and can attain a maximum final pressure of 1.600 $\mathrm{kPa}$ and an electric power of $5 \mathrm{~kW}$, was selected. The electricity consumed by the compressor is determined by the following equation:

$$
\mathrm{E}_{\text {Comp }}=\mathrm{P}_{\text {Comp }}\left(\frac{\mathrm{V}_{\text {biogas }}}{\phi_{\text {Comp }}}\right)
$$


Where,

$\mathrm{E}_{\text {Comp }}=$ Electricity consumed by the compressor $[\mathrm{kWh}]$

$\mathrm{P}_{\text {Comp }}=$ Electric power consumed by the compressor $[\mathrm{kW}]$,

$\phi_{\text {comp. }}=$ Volumetric flow rate of compression $\left[\mathrm{m}^{3} \mathrm{~h}^{-1}\right]$.

To optimize the process, the residual heat from the exhaust gases was employed, which heated the microturbine near $548 \mathrm{~K}$. The Capstone ITC 1 heat recovery unit, which can be directly connected to the exhaust pipe of the microturbine. The heat recovery unit has a water pump of $1.5 \mathrm{~kW}$ of power to promote the circulation of water inside the pump, which allows the water to heat to $368 \mathrm{~K}$. The electricity consumed by the pump of the heat recovery unit is obtained by the following equation:

$$
E_{\text {Rec }}=P_{\text {Rec }} \cdot t_{\text {Rec }}
$$

Where,

$\mathrm{E}_{\mathrm{Rec}}=$ Electricity consumed by the heat pump [kWh];

$\mathrm{P}_{\mathrm{Rec}}=$ Electric power consumed by the heat pump $[\mathrm{kW}]$,

$t_{\text {Rec }}=$ Time of operation of the heat recovery unit $[\mathrm{h}]$.

The volume of heated water produced by the heat recovery unit is calculated by the following equation:

$$
\mathrm{Q}_{\mathrm{h}}=\frac{\dot{\mathrm{m}}_{\mathrm{gas}} \cdot \mathrm{Cp}_{\mathrm{gas}} \cdot\left(\mathrm{T}_{\mathrm{er}}-\mathrm{T}_{\mathrm{sr}}\right)}{\mathrm{Cp}_{\mathrm{H} 2 \mathrm{O}} \cdot \rho_{\mathrm{H} 2 \mathrm{O}} \cdot\left(\mathrm{T}_{\mathrm{h}}-\mathrm{T}_{\mathrm{a}}\right)} \cdot\left(3600 \cdot \mathrm{t}_{\mathrm{rec}}\right)
$$

Where,

$\mathrm{Q}_{\mathrm{h}}=$ Volume of water heated to $368 \mathrm{~K}\left[\mathrm{~m}^{3}\right]$;

$\dot{\mathrm{m}}_{\text {gas }}=$ Mass flow rate of microturbine exhaust gases $\left[\mathrm{kg} \mathrm{s}^{-1}\right]$;

$\mathrm{Cp}_{\text {gas }}=$ Specific heat of exhaust gases [kJ kg-1 $\mathrm{K}^{-1}$;

$\mathrm{T}_{\mathrm{er}}=$ Exhaust gas temperature at the inlet of the heat recovery unit $[\mathrm{K}]$;

$\mathrm{T}_{\mathrm{sr}}=$ Exhaust gas temperature at the outlet of the heat recovery unit $[\mathrm{K}]$;

$\mathrm{Cp}_{\mathrm{H} 2 \mathrm{O}}=$ Specific heat of water $\left[\mathrm{kJ} \mathrm{kg}^{-1} \mathrm{~K}^{-1}\right]$;

$\mathrm{T}_{\mathrm{h}}=$ Water temperature at the outlet of the heat recovery unit $[\mathrm{K}]$;

$\mathrm{T}_{\mathrm{a}}=$ Water temperature at the inlet of the heat recovery unit $[\mathrm{K}]$,

$\rho_{\mathrm{H} 2 \mathrm{O}}=$ Specific mass of water $\left[\mathrm{kg} \mathrm{m}^{-3}\right]$.

For the calculations, the following properties were considered:

Water: $\quad \rho_{\mathrm{H} 2 \mathrm{O}}=1.000 \mathrm{~kg} \mathrm{~m}^{-3}, \quad \mathrm{Cp}_{\mathrm{H} 20}=4,22 \mathrm{~kJ} \mathrm{~kg}^{-1}$. $\mathrm{K}^{-1}, \mathrm{~T}_{\mathrm{a}}=298 \mathrm{~K}, \mathrm{~T}_{\mathrm{h}}=368 \mathrm{~K}$.
Exhaust gases: $\quad \dot{\mathrm{m}}_{\text {gas }}=0.31 \mathrm{~kg} \mathrm{~s}^{-1}, \quad \mathrm{Cp}_{\text {gas }}=$ $1,00 \mathrm{~kJ} \mathrm{~kg}^{-1} \mathrm{~K}^{-1}, \mathrm{~T}_{\mathrm{er}}=584 \mathrm{~K}, \mathrm{~T}_{\mathrm{sr}}=398 \mathrm{~K}$.

For the energy exploitation of the exhaust gases used for cooling, we used a liquid chiller (absorption chiller) that employs the heated water produced by the heat recovery unit as its heat source. The selected liquid chiller was an LWM-W003 model, from the LS GROUP, which operates with hot water at low temperatures and uses lithium bromide $(\mathrm{LiBr})$ as the absorbent and water as the refrigerant. In normal conditions, $98.56 \mathrm{~kW}$ of cooling can be produced with $8 \mathrm{~m}^{3} \mathrm{~h}^{-1}$ of water heated to $368 \mathrm{~K}$. In addition, the chiller is equipped with a hydraulic pump that promotes the circulation of the absorbent in the system and other electrical components that demand a total electric power of $1.4 \mathrm{~kW}$.

The cooling capacity of the liquid chiller for partial loads of thermal energy applied to the chiller generator is obtained based on the full-load coefficient of performance (COP), the amount of available thermal energy and the amount of operating time, as given by the following equation:

$Q_{F}=C O P_{a b s} \cdot\left\{\left[\dot{m}_{g a s} \cdot C p_{g a s} \cdot\left(T_{s r}-T_{e r}\right)\right]+w_{b}\right\} \cdot t_{C h i}$

Where,

$Q_{F}=$ Cooling capacity of the chiller $[\mathrm{kWh}] ;$

$C O P_{a b s}=$ Coefficient of performance (yield) of the chiller;

$Q_{G}=$ Heat injected into the chiller $[\mathrm{kW}]$;

$w_{b}=$ Electric power consumed by chiller pump [kW],

$t_{C h i}=$ Operating time of the chiller $[\mathrm{h}]$.

The energy used by the chiller pump can be obtained according to the following equation:

$$
\mathrm{E}_{\text {Chi }}=\mathrm{P}_{\text {Chi }} \cdot \mathrm{t}_{\text {Chi }}
$$

Where,

$E_{C h i}=$ Energy consumed by the chiller pump [kWh];

$P_{C h i}=$ Electric power of the chiller pump $[\mathrm{kW}]$,

$t_{C h i}=$ Operating time of the chiller $[\mathrm{h}]$.

\section{RESULTS AND DISCUSSION}

Considering the analyzed rural property, organic manure from 240 dairy cows is collected daily for the biodigester. Considering the average production of 40 $\mathrm{kg}$ animal $^{-1}$ of fresh manure daily and based on the study by Baungratz et al. (2013), each cow is capable of producing between 1.6 and $1.96 \mathrm{~m}^{3}$ of biogas per day. Therefore, with the manure collected from the 240 animals, producing approximately 384 to $470.4 \mathrm{~m}^{3}$ of biogas per day is possible.

The percentage of methane gas in the biogas used for this study was suggested by Suzuki et al. (2014). According to Bonturi \& Dijk (2012), the lower calorific value (LCV) of methane gas is approximately 35,857 $\mathbf{k J ~} \mathbf{~ m}^{-3}$. Therefore, the calorific value of biogas varies between $14,343 \quad \mathbf{k J ~ N m}^{-3} \quad\left(40 \%\right.$ of $\left.\mathbf{C H}_{\mathbf{4}}\right)$ and $26,893 \mathbf{~ k J ~ N ~ m}{ }^{-3}$ ( $75 \%$ of $\mathbf{C H}_{4}$ ). Figure 1 illustrates the calorific value of the biogas. 


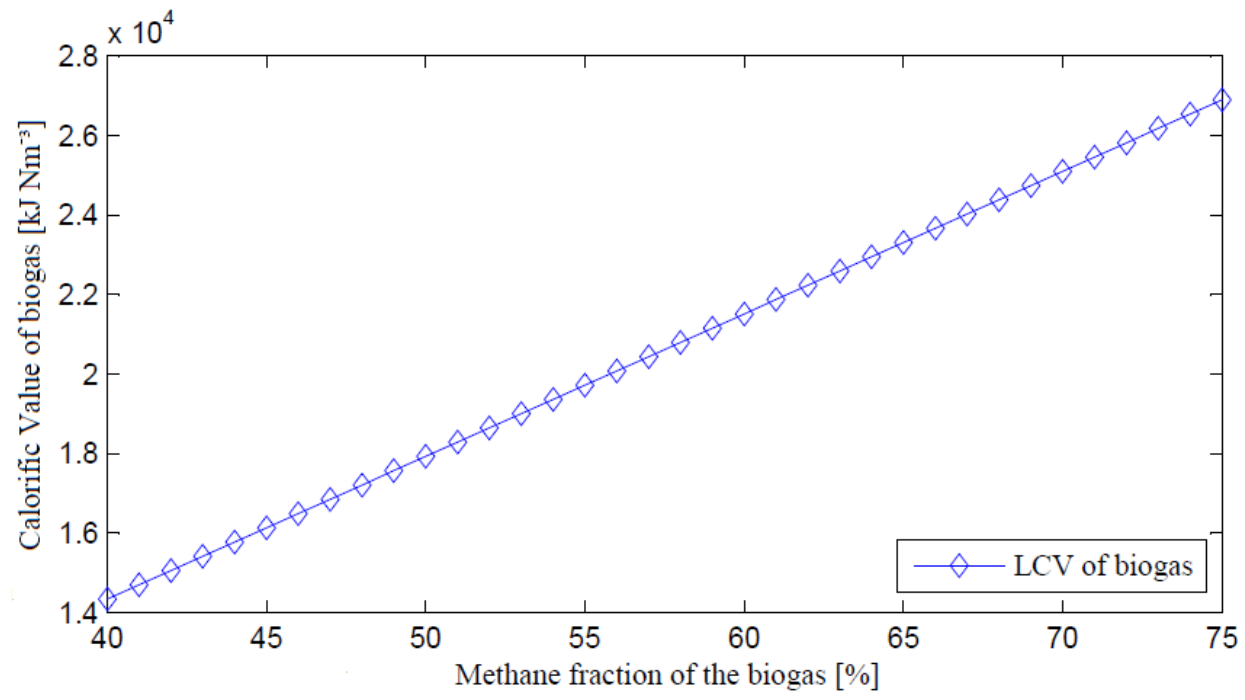

FIGURE 1. LCV of the biogas as a function of the methane gas in its composition (according to Suzuki et al. (2014) and Bonturi \& Dijk (2012)).

The energy potential of a dairy cow can be determined by the amount and calorific value of produced biogas; thus, a

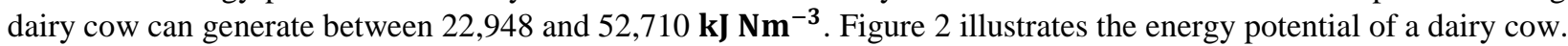

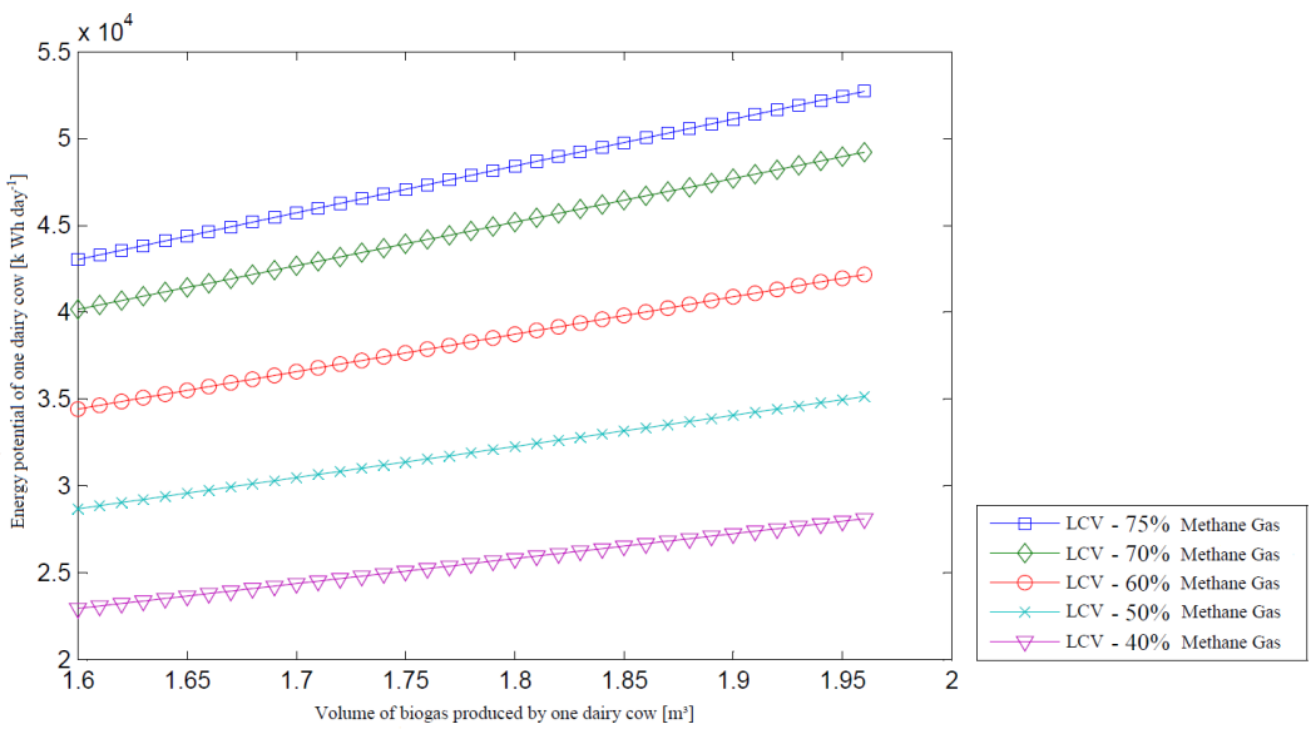

FIGURE 2. Potential energy that can be obtained by biodigestion of organic waste of dairy cattle.

The energy production of the microturbine varies according to the LCV of the biogas and the ambient operating conditions. According to the Centro Integrado de Informações Agrometeorológicas (CIAGRO, 2014), the average maximum temperature in the municipality of Buritama is approximately $303 \mathrm{~K}$. Therefore, the daily electricity production of the microturbine is approximately 313.3 to $383 \mathrm{kWh} \mathrm{day}^{-1}$ for a biogas with a composition that includes $40 \%$ methane gas. For a biogas rich in methane gas $(75 \%), \quad 587.5$ to $719.7 \mathrm{kWh} \mathrm{day}^{-1}$ of electricity can be obtained. For this case, the energy available in the biogas is higher than the energy conversion capacity of the selected microturbine, which causes a surplus of produced biogas and limits the microturbine production to $624 \mathrm{kWh} \mathrm{day}^{-1}$. In the study by Singh \& Jash (2015), $124.59 \mathrm{~m}^{3}$ of cattle biogas was employed in a gas microturbine to produce 162.77 $\mathrm{kWh}$ day $^{-1}$ of electricity.

The compressor requires $5.0 \mathrm{kWh}$ of energy to compress approximately $26.7 \mathrm{~m}^{3} \mathrm{~h}^{-1}$ of biogas to increase the biogas pressure to the level required by the microturbine. Therefore, the energy consumption of the compressor ranges from 71.9 to $88.1 \mathrm{kWh}$ day $^{-1}$. Figure 3 shows the energy production of the microturbine and the energy consumption of the compressor as a function of the number of animals on the property, depending on the daily production of biogas and its LCV. 


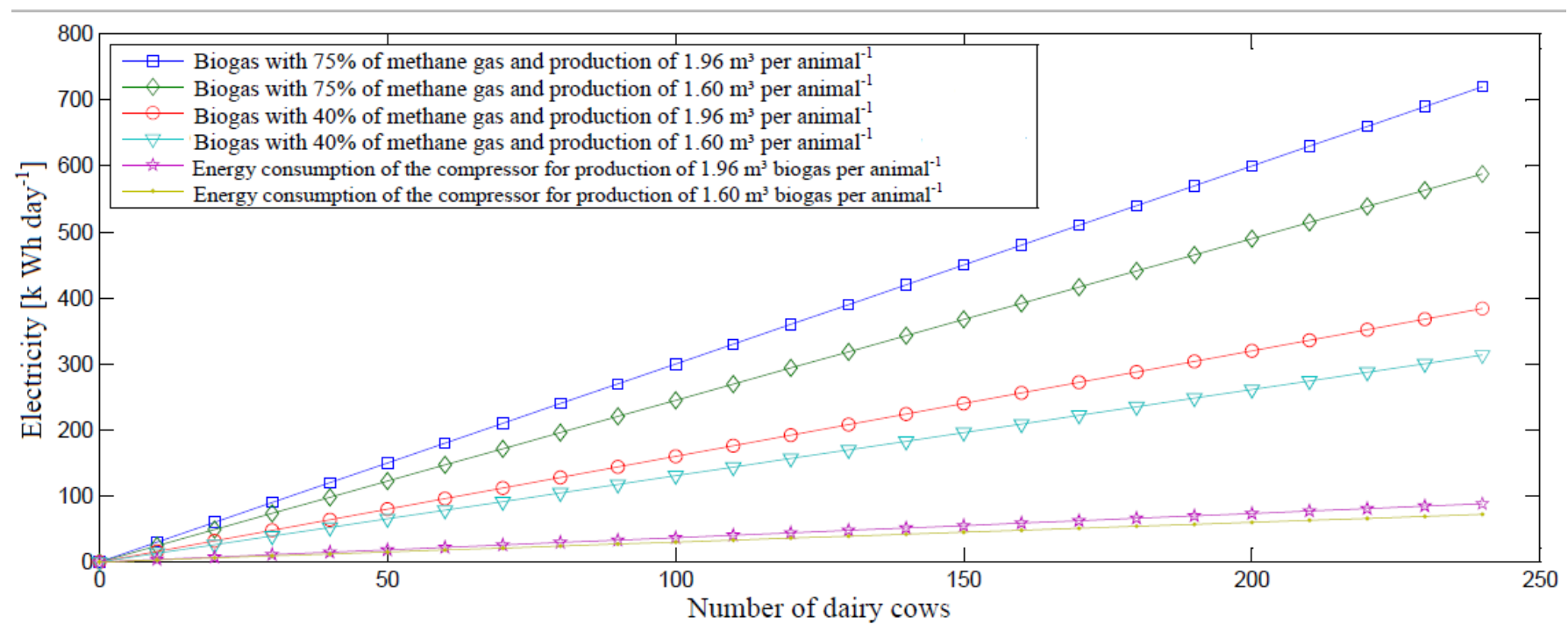

FIGURE 3. Energy production of the microturbine and energy consumption of the compressor as a function of the number of dairy cows.

The net energy production of the microturbine was obtained by subtracting the energy consumption of the compressor from the energy produced by the microturbine. This finding indicates a production of 241.4 to $535.9 \mathrm{kWh}^{\mathrm{day}}{ }^{-1}$ of electricity. Figure 4 shows the net electricity production of the microturbine as a function of the number of animals on the property, depending on the daily biogas production and its energy value (LCV).

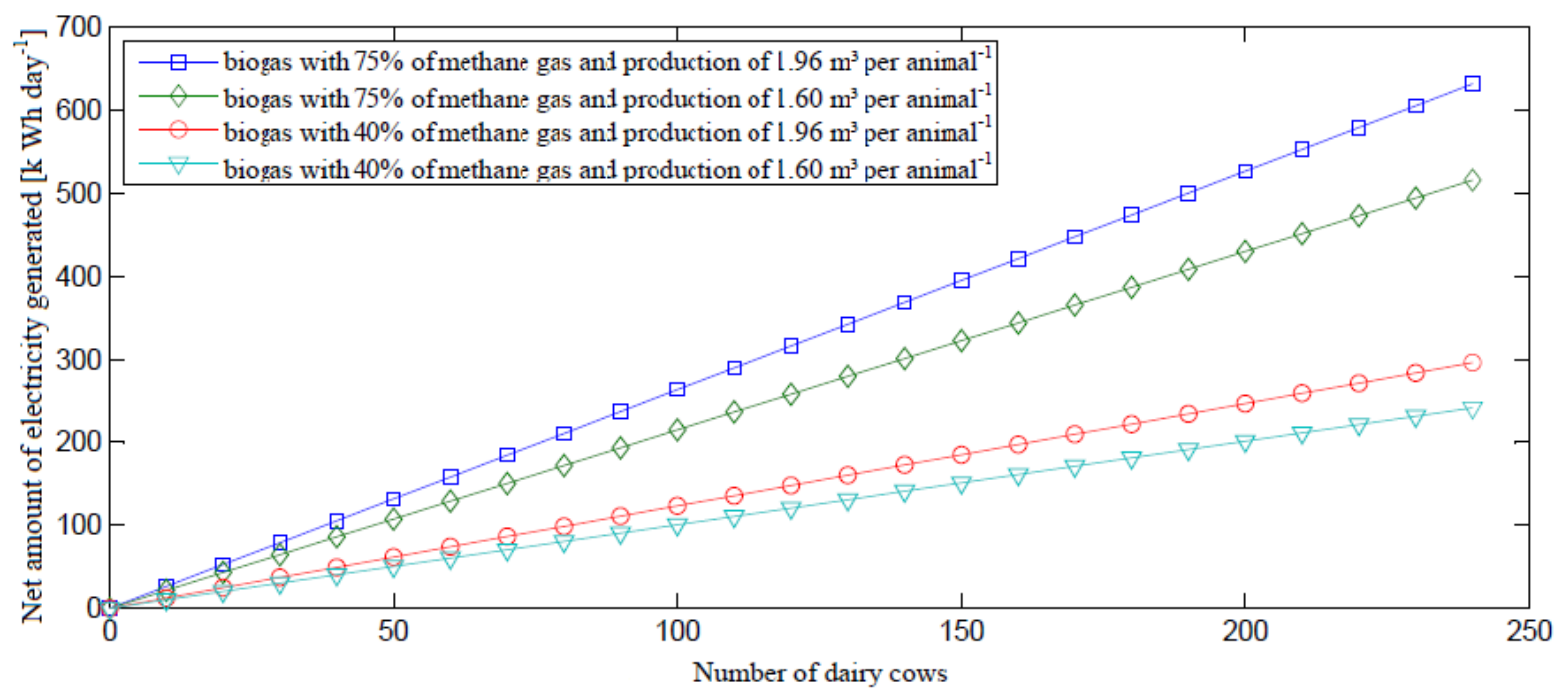

FIGURE 4. Net electricity generation of the microturbine.

The amount of water heated to $368 \mathrm{~K}$ was obtained via the exploitation of the microturbine's exhaust gases thermal energy using a heat recovery unit. Considering that the recovery unit will be working during the entire period of operation of the microturbine, approximately 6.8 to $13.6 \mathbf{~ m}^{\mathbf{3}} \mathbf{d a y}^{-\mathbf{1}}$ of heated water (maximum production of heated water, limited by the operation of the microturbine) can be obtained. Figure 5 illustrates the amount of water heated to $368 \mathrm{~K}$ produced by the recovery unit as a function of the number of animals on the property, depending on the production and the LCV of the biogas. 


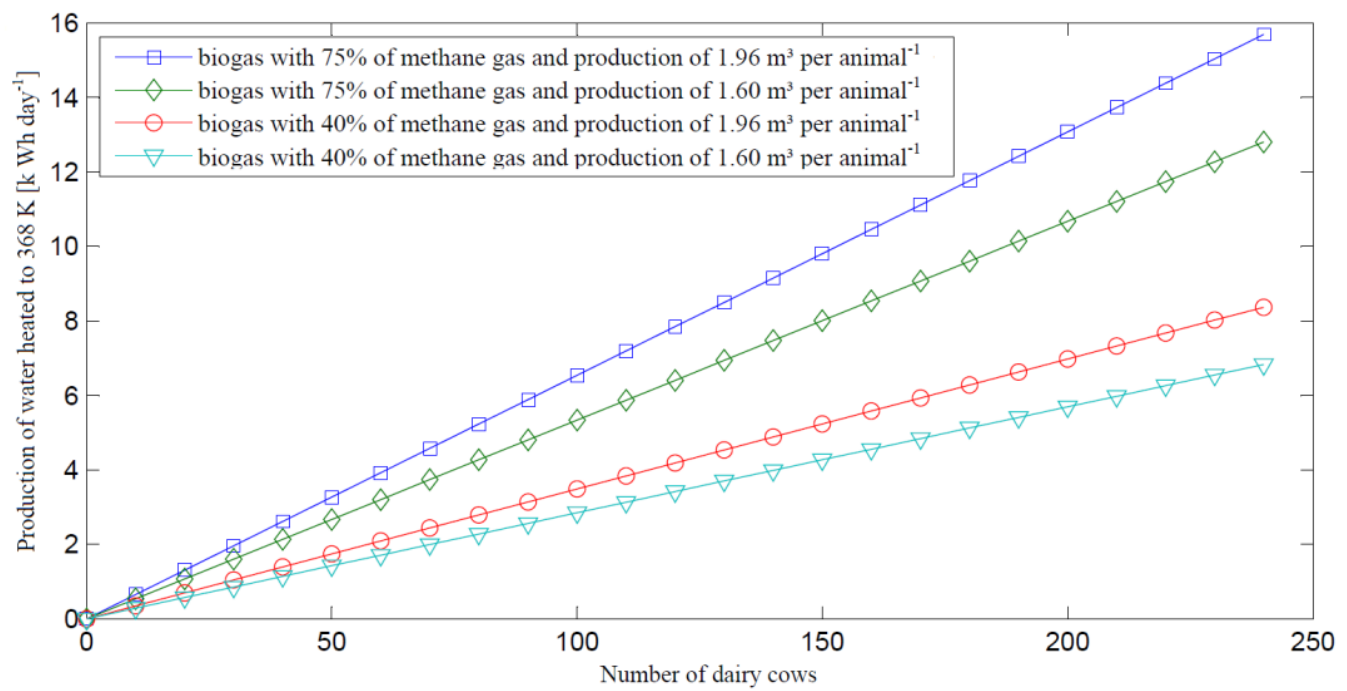

FIGURE 5. Quantity of heated water (368 K) produced by the heat recovery unit.

The recovery unit operates with the aid of a hydraulic pump to promote water circulation. In this manner, the net amount of electricity supplied by the microturbine ranges between 223.3 and $499.9 \mathbf{k W h ~ d a y ~}^{\mathbf{- 1}}$. Figure 6 shows the net electricity production (electricity generated by the microturbine, which does not account for the energy consumption of the compressor and the recovery unit pump) as a function on the number of animals on the property, depending on the production and the LCV of the biogas.

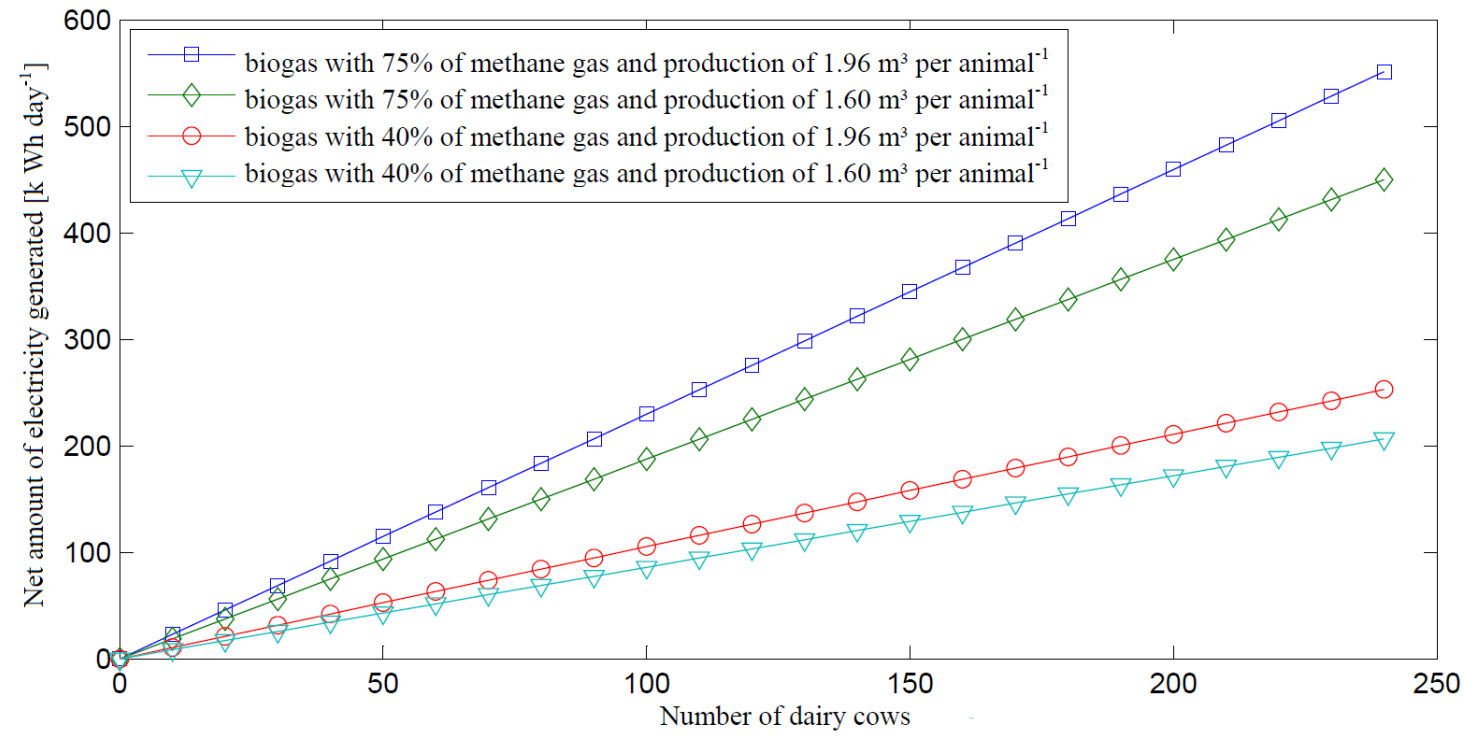

FIGURE 6. Net electricity generation of the microturbine with water heating.

For energy consumption for cooling, the heat from the water heated through the recovery unit can serve as the hot source of a chiller. In this scenario, the refrigeration load provided by the chiller ranges between 396.0 and $788.7 \mathrm{kWh} \mathrm{day}^{-1}$ (maximum cooling capacity limited by the microturbine operation). Figure 7 illustrates the cooling capacity that can be obtained by the chiller as a function of the number of animals on the property, depending on the daily production of biogas and its LCV.
The chiller requires $1.4 \mathrm{~kW}$ of electric power for the activation of its electrical components and the hydraulic pump; therefore, the electricity consumed by the chiller is $33.6 \mathbf{~ k W h}$ day $^{-\mathbf{1}}$. Subtracting the consumption values of the biogas compressor, the heat pump, the chiller pump and other electrical components, the electricity produced by the microturbine ranges between 206.5 and $466.3 \mathbf{k W h} \cdot \mathbf{d a y}^{\mathbf{- 1}}$. Figure 8 shows the net electricity production of the microturbine as a function of the number of animals on the property, depending on the production and the LCV of the biogas. 


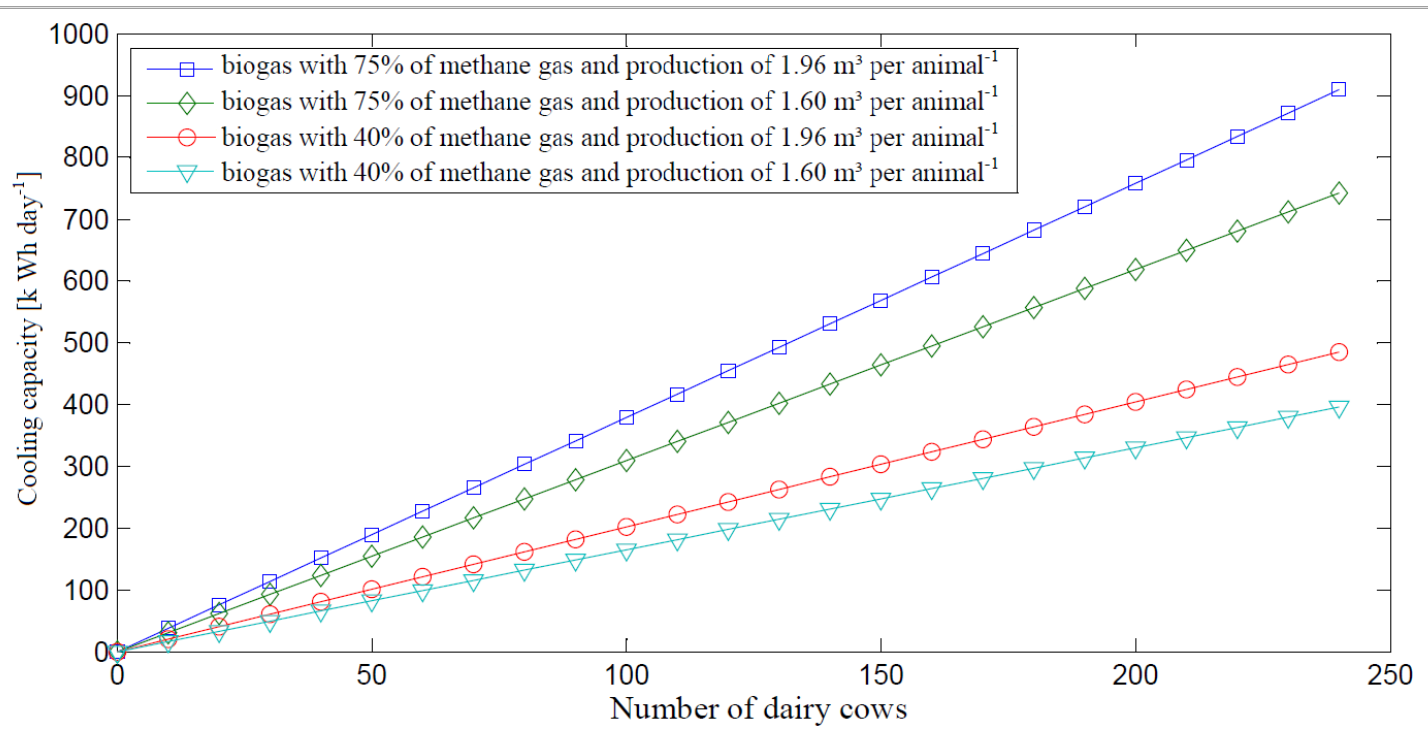

FIGURE 7. Cooling capacity provided by the liquid chiller.

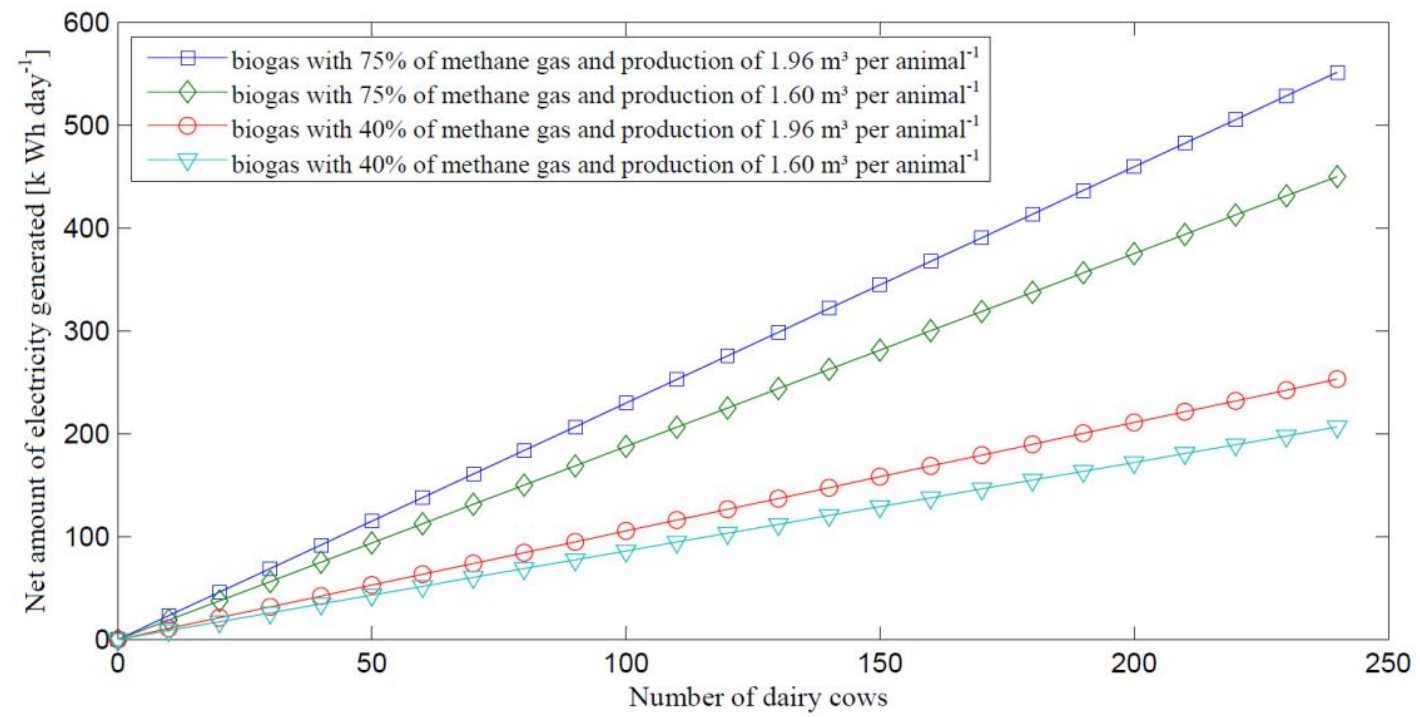

FIGURE 8. Net electricity generation of the microturbine with cooling (chiller).

Considering the conditions of the daily production of cattle manure, the potential for converting organic matter and a biogas with 50\% methane gas in its composition, Figure 9 illustrates the amount of electricity generated by the microturbine and the amount of electricity consumed by the equipment used for the compression of the biogas, the heating of water and liquid cooling, based on the daily production of $1.6 \mathrm{~m}^{3}$ of biogas per animal.
Figure 10 illustrates the net amount of electricity that can be supplied by direct generation (microturbine electricity generation, subtracting the energy consumption of the gas compressor) via energy exploitation with water heating (generation of electricity from the microturbine, subtracting the energy portion related to the gas compressor and the heat recovery unit pump) and liquid cooling (generation of electricity in the microturbine, subtracting the consumption of the gas compressor, the heat recovery unit and the chiller pump). 


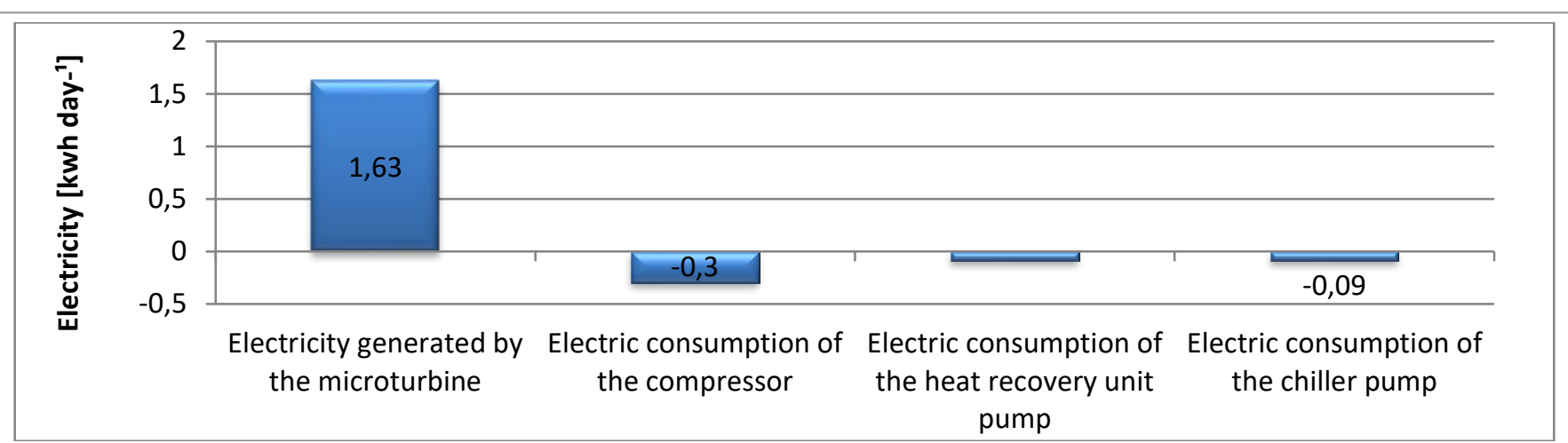

FIGURE 9. Electricity generated by the microturbine and the electric consumption of the equipment for the following cases: direct generation, using water heating and liquid cooling, obtained per animal with a biogas that contains $50 \%$ of methane gas in its composition.

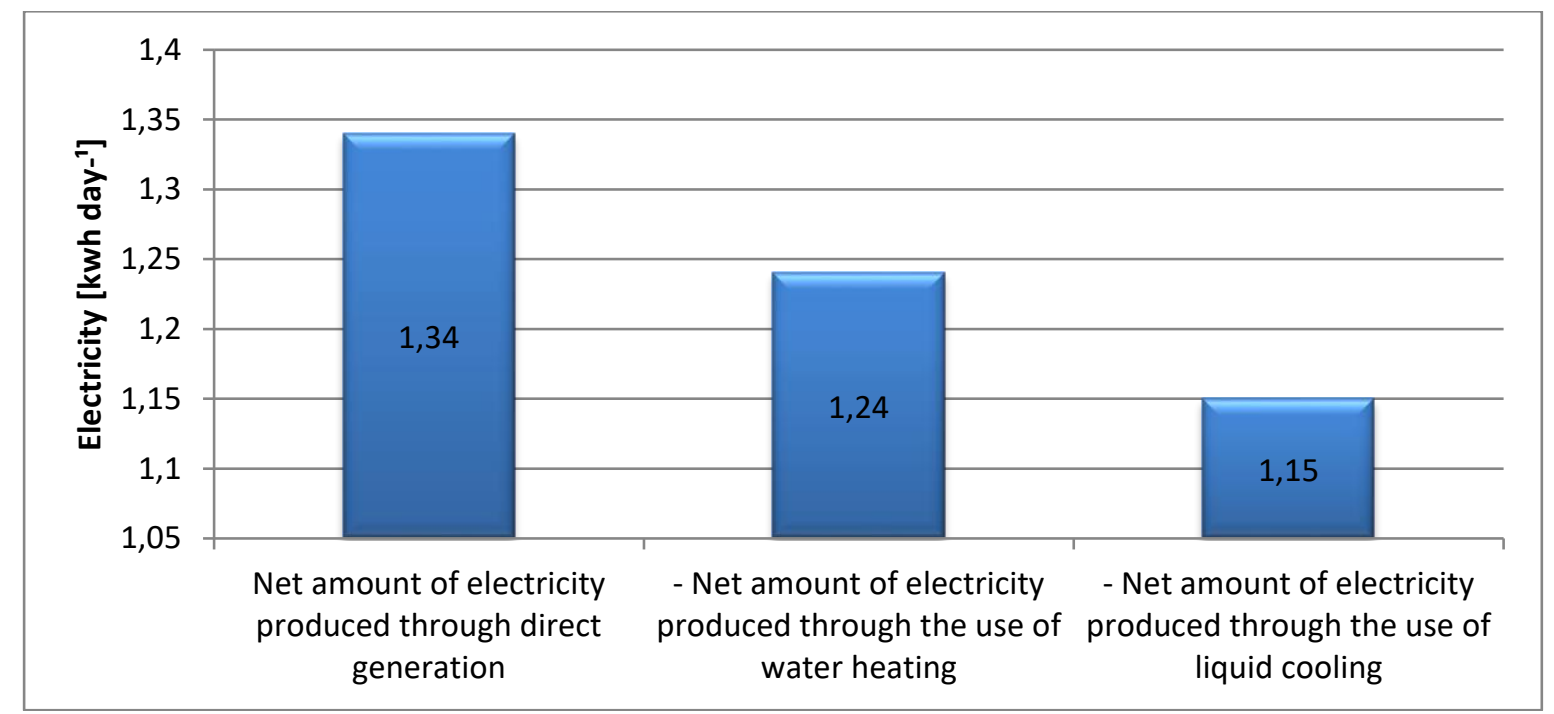

FIGURE 10. Net electricity supply for the following cases: direct generation using water heating and liquid cooling, obtained per animal with a biogas that contains $50 \%$ of methane gas in its composition.

The energy potential of the produced biogas, the amount of electricity generated by the microturbine, the amount of energy contained in the volume of heated water produced by the heat exchanger, and the cooling capacity obtained by the chiller can be obtained, as illustrated in Figures 11 and 12. The total efficiency of the electricity generation process with water heating is $57.1 \%$, and that for the electricity generation process with liquid cooling is $46.4 \%$. Yingjian et al. (2011) obtained an energy efficiency of $61.8 \%$ for the combined-cycle power generation with water heating. Rocha et al. (2012) obtained an energy efficiency of $52.9 \%$ for the combined-cycle power generation with liquid cooling.

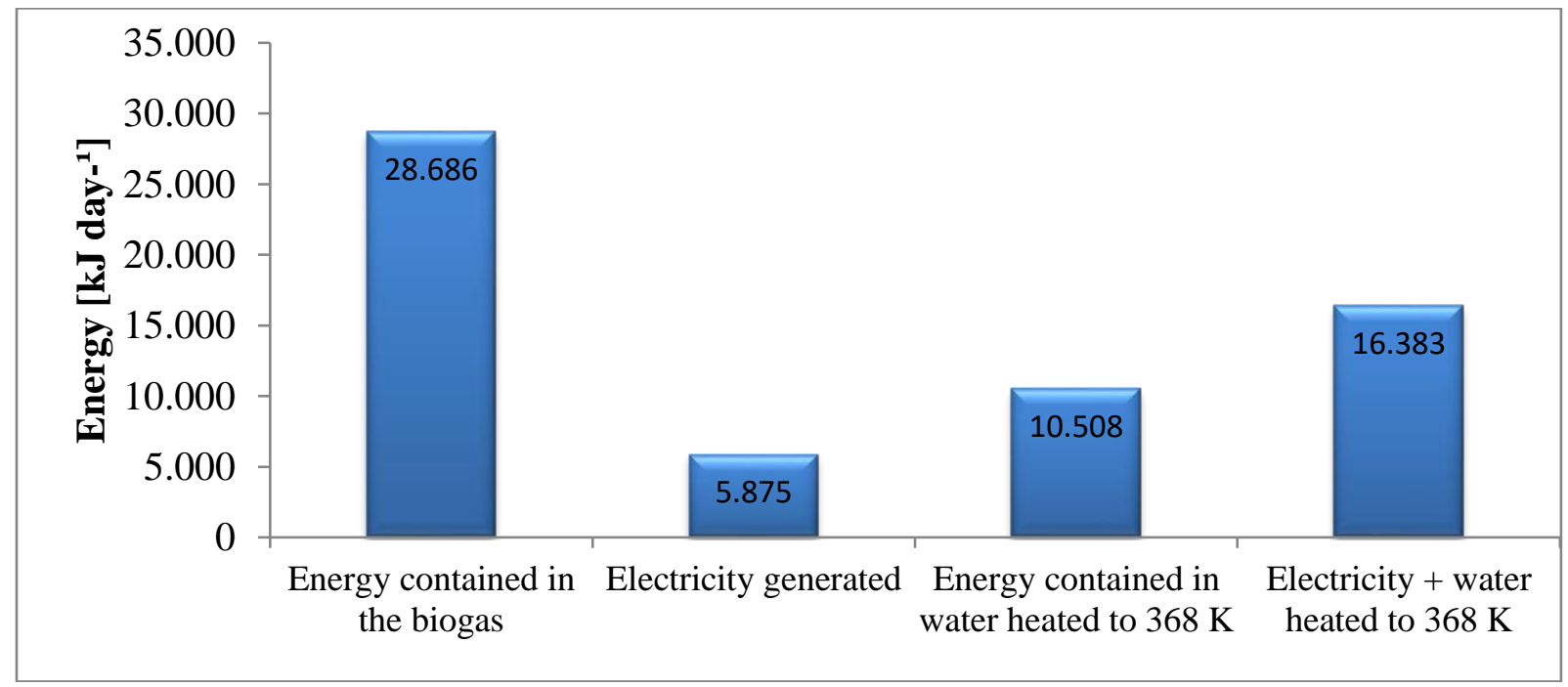

FIGURE 11. Amount of energy contained in the biogas, generated electricity and volume of heated water produced (obtained per animal with $50 \%$ methane gas in the biogas composition). 


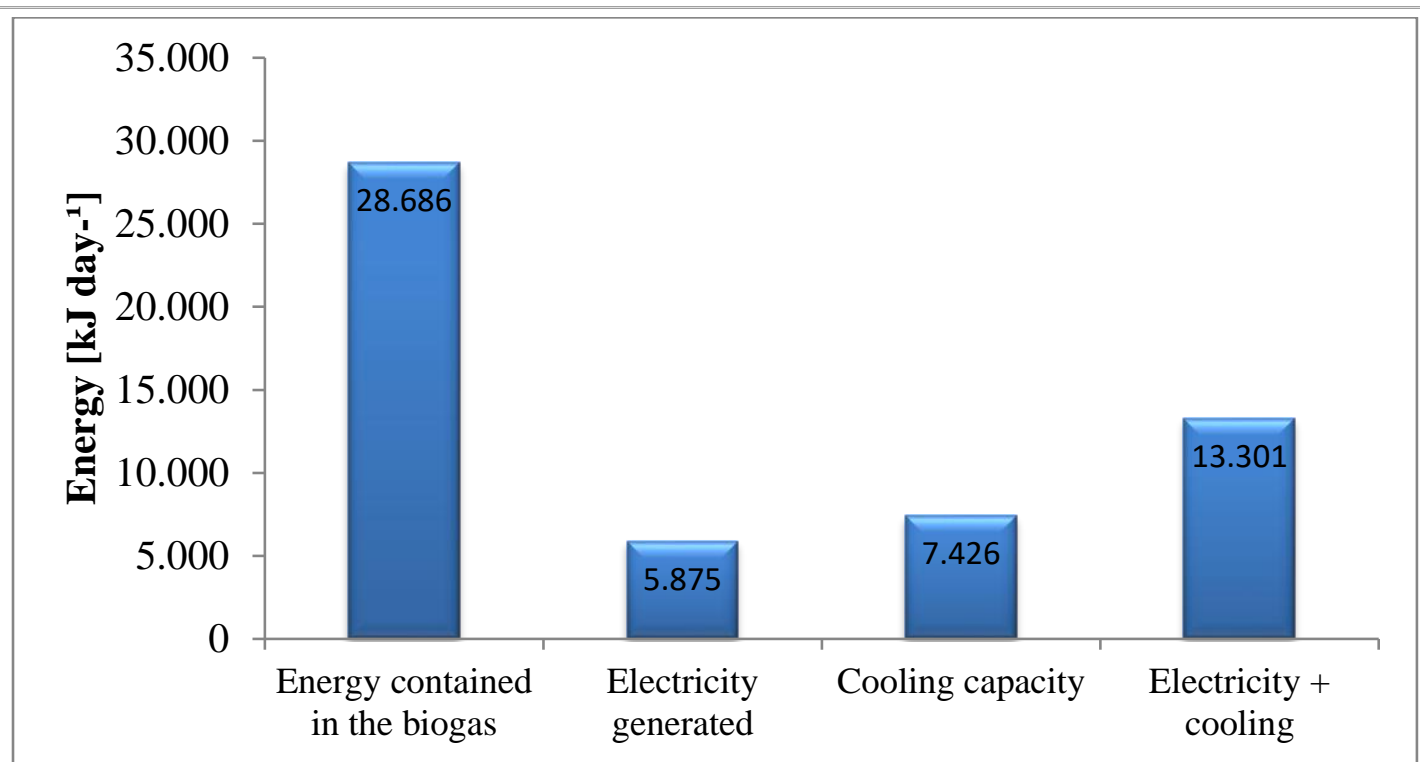

FIGURE 12. Amount of energy contained in the biogas, electricity generated and cooling capacity produced by the liquid chiller (obtained per animal with 50\% methane gas in the biogas composition).

The cost of the installed energy can be calculated by the costs of the equipment for the electricity generation and the equipment for the thermal exploitation of the exhaust gases. Table 1 presents the approximate costs of the equipment, considering a US Dollar to Brazilian Real exchange rate of R $\$ 3.20$. Table 2 presents the cost of one MWh of electricity and the cost of the minimum and maximum annual savings of electricity that can be achieved in the three analyzed scenarios. Table 3 shows the Net Present Value (NPV) at a rate of $7 \%$ p.a., Internal Return Rate (IRR) and the investment's payback for fiveyear intervals.

TABLE 1. Approximate cost of the equipment for electricity generation and thermal recovery.

\begin{tabular}{cc}
\hline Equipment & Approximate cost (R\$) / (US\$) \\
\hline Capstone Microturbine + TRE200 Biogas Compressor & $380,000.00 / 118,750.00$ \\
Capstone Heat Exchanger & $36,000.00 / 11,250.00$ \\
LWM-W003 Liquid chiller & $80,000.00 / 25,000.00$ \\
\hline
\end{tabular}

TABLE 2. Approximate cost of electricity and estimates of annual energy savings.

\begin{tabular}{|c|c|c|c|}
\hline & $\begin{array}{c}\text { Approximate cost } \\
(\mathbf{R} \$)\end{array}$ & \multicolumn{2}{|c|}{$\begin{array}{c}\text { Estimated annual energy savings }(\mathrm{R} \$) \text { - } \\
\text { Minimum/maximum }\end{array}$} \\
\hline Electrıcity (MWh) & & & \\
\hline Direct energy generation (I) & & $18,231.59$ & $40,473.52$ \\
\hline Energy generation + water heating (II) & & $16,846.60$ & $37,754.65$ \\
\hline Energy generation + liquid cooling (III) & & $15,595.79$ & $35,217.03$ \\
\hline
\end{tabular}

TABLE 3. NPV, IRR and Payback values for five-year intervals.

\begin{tabular}{|c|c|c|c|c|c|c|}
\hline & & After five years & & & After ten years & \\
\hline Scenario & $\begin{array}{l}\text { NPV }(\text { R\$) - } \\
\text { min/max }\end{array}$ & $\operatorname{IRR}(\%)-\min / \max$ & $\begin{array}{c}\text { Payback } \\
\text { (years) }\end{array}$ & $\begin{array}{l}\text { NPV }(\mathbf{R} \$)- \\
\min / \mathbf{m a x}\end{array}$ & $\operatorname{IRR}(\%)-\min / \mathrm{Max}$ & $\begin{array}{c}\text { Payback } \\
\text { (years) }\end{array}$ \\
\hline $\mathbf{I}$ & $\begin{array}{c}-305,246.88 / \\
-214,050.58\end{array}$ & $--/-17.90$ & --/-- & $\begin{array}{c}-251,948.94 / \\
-95,730.93\end{array}$ & $-11.52 / 1.16$ & $--/-$ \\
\hline II & $\begin{array}{l}-346,851.81 / \\
-216,198.48\end{array}$ & $--/-21.64$ & $--/--$ & $\begin{array}{l}-297,550.11 / \\
-150,827.14\end{array}$ & $-13.76 /-1.73$ & $--/--$ \\
\hline III & $\begin{array}{l}-432,054.18 / \\
-351,603.22\end{array}$ & $--/--$ & $--/--$ & $\begin{array}{l}-386,461.89 / \\
-248,650.32\end{array}$ & $--/-5.70$ & $--/--$ \\
\hline Scenario & $\begin{array}{c}\text { NPV }(\text { R\$) - } \\
\min / \max \end{array}$ & $\begin{array}{l}\text { After } 15 \text { years } \\
\text { IRR }(\%)-\min / \max \end{array}$ & $\begin{array}{c}\text { Payback } \\
\text { (years) }\end{array}$ & $\begin{array}{c}\text { NPV }(\mathbf{R} \$)- \\
\min / \max \end{array}$ & $\begin{array}{c}\text { After } 20 \text { years } \\
\text { IRR }(\%)-\min / \text { Max }\end{array}$ & $\begin{array}{c}\text { Payback } \\
\text { (years) }\end{array}$ \\
\hline I & $\begin{array}{c}-213,948.25 / \\
-11,370.66\end{array}$ & $-3.86 / 6.52$ & $--/-$ & $\begin{array}{c}-186,854.28 / \\
48,777.05\end{array}$ & $-0.38 / 8.61$ & $16^{\text {th }}$ year \\
\hline II & $\begin{array}{c}-262,398.67 / \\
-72,133.89\end{array}$ & $-5.66 / 4.13$ & $--/-$ & $\begin{array}{c}-237,336.19 / \\
-16,026.70\end{array}$ & $-1.92 / 6.50$ & $--/--$ \\
\hline III & $\begin{array}{l}-353,954.70 / \\
-175,246.32 \\
\end{array}$ & $-8.20 / 0.80$ & $--/--$ & $\begin{array}{l}-330,777.98 / \\
-122,910.28 \\
\end{array}$ & $-4.06 / 3.59$ & $--/--$ \\
\hline
\end{tabular}




\section{CONCLUSIONS}

This study demonstrated the possibility of performing the energetic exploitation of biogas in microturbines with the possibility of generating between 6,195 and $16,077 \mathrm{kWh} \cdot$ month $^{-1}$ of net electricity, which can supply at least $43.3 \%$ of the property's energy demand or even make it self-sufficient since the farm requires approximately $14,300 \mathrm{kWh} \cdot \mathrm{month}^{-1}$ of electricity for raising 336 dairy cattle and collecting and storing 3,000 liters of milk per day. By performing thermal exploitation, between 6.8 and $13.6 \mathrm{~m}^{3} \cdot$ day $^{-1}$ of water heated to $368 \mathrm{~K}$, which could be used for cleaning and sterilizing the milking environment and the equipment for milk production, can be produced. Alternatively, the heated water can be employed to activate a chiller that enables a cooling capacity between 11,880 and 23,661 kWh . month $^{-1}$, which can be used for cooling environments or to decrease the temperature of the milk product prior to storage.

The energy exploitation of the microturbine's exhaust gases increases the energy efficiency of the process, which enables an energy yield of $57.1 \%$ for the process of electricity generation with water heating and $46.4 \%$ for the process of electricity generation with liquid cooling.

With regard to the investment's financial analysis, considering an interest rate of $7 \%$ p.a. (average approximate inflation rate of the last decade), only in the process of electricity generation with methane-rich biogas and high daily production, a return on investment after 16 years is possible. In other cases, no investment payback is observed in the first 20 years, which discourages their adoption. However, note that the implementation of new tax incentives in the microgeneration sector can reduce the initial costs and payback time of the investment, which render it profitable and attractive.

\section{ACKNOWLEDGMENTS}

The author thanks the Brazilian Federal Agency for the Support and Evaluation of Graduate Education (CAPES) for its scientific and financial support, and the owners and employees of the Vovó Cida farm, who allowed us to study their property and contributed by providing data that made this study feasible.

\section{REFERENCES}

Baungratz KL, Oliveira JB, Slongo N, Frigo EP, Zanon E (2013) Produção de biogás a partir de biomassa residual. Revista Acta Iguazu 2(3):30-39.

Bonturi GD, Dijk MV (2012) Instalação de biodigestores em pequenas propriedades rurais: análise de vantagens socioambientais. Revista Ciências do Ambiente On-Line $8(2): 88-95$.
Capstone Turbine Corporation. Available in: http:/www.capstoneturbine.com. Accessed: Sep 20, 2014.

CIAGRO - Centro Integrado de Informações

Agrometeorológicas. Temperatura média mensal.

Available in: https://goo.gl/hFK9B. Accessed: Sep 20, 2014.

Da Costa LV, Moghrabi JA, Sagula AL, Junior JL (2013) Tratamento anaeróbico da água residuária de frigorífico com uso de biodigestores: utilização de remediadores biológicos para produção de biogás. Brazilian Journal of Biosystems Engineering 7(2):77-85.

Fonseca LD, Vieira TM, Lázaro SF, Silva MLF, Ferreira AVP, Bastos GA, Morais-Costa F, Martins ER, Duarte ER (2014) Eficácia in vitro de extratos aquosos de plantas no controle de nematódeos gastrintestinais de bovinos. Revista Acta Scientiae Veterinariae 42(1):1-8.

Gregory L, Rossi RS, Mendes JP, Neuwirt N, Marques EC, Melville PA (2014) Ocorrência dos principais agentes bacterianos e parasitários em fezes diarreicas de bezerros búfalos nos estados de São Paulo e Paraná. Revista Arquivos do Instituto Biológico 81(2):180-185. Available in: https://goo.gl/NEU9Bb. DOI:

http://dx.doi.org/10.1590/1808-1657001122012

LS GROUP. Available in: https://goo.gl/3VB83H. Accessed: Oct 5, 2014.

Mehrer Customized Compression. Available in: https://goo.gl/UUhQ3G. Accessed: Sep 14, 2014.

Rocha MS, Andreos R, Moreira JRS (2012) Performance tests of two small trigeneration pilot plants. Applied Thermal Engineering 41:84-91.

Singh K, Jash T (2015) Performance analysis of micro turbine-based grid-connected biogas power plant in Purulia in West Bengal, India. Clean Technologees and Environmental Policy 17(3):789-795.

Suzuki ABP, Fernandes DM, Faria RAP, Souza SMN (2014) Produção de biogás em escala real em unidade demonstrativa - Unidade Granja Colombari. Ambiência Revista do Setor de Ciências Agrárias e Ambientais 10(1):13-20. Available in:

http://200.201.10.18/index.php/ambiencia/article/view/139 2/2210. DOI:

http://dx.doi.org/10.5935/ambiencia.2014.01.01

Yingjian L, Qi Q, Xiangzhu H, Jiezhi L (2011) Energy use project and conversion efficiency analysis on biogas produced in breweries. In: World Renewable Energy Congress. Sweden. 